\title{
The single Andigenum origin of Neo-Tuberosum potato materials is not supported by microsatellite and plastid marker analyses
}

\author{
Marc Ghislain • Jorge Núñez • \\ María del Rosario Herrera $\cdot$ David M. Spooner
}

Received: 26 June 2008 / Accepted: 8 December 2008 / Published online: 9 January 2009

(C) The Author(s) 2008. This article is published with open access at Springerlink.com

\begin{abstract}
Neo-Tuberosum refers to cultivated potato adapted to long-day tuberization and a syndrome of related morphological and physiological traits, developed by intercrossing and selection of short-day adapted potatoes of the Solanum tuberosum Andigenum Group, native from the Andes of western Venezuela to northern Argentina. This re-creation of the modern potato helped support the theory of an Andigenum Group origin of potato in temperate regions and the possibility to access the largely untapped diversity of the Andigenum Group germplasm by base broadening breeding. This Neo-Tuberosum derived theory, the re-creation of the modern potato from Andigenum germplasm, has been universally accepted for almost 40 years, and has had tremendous impact in planning some breeding programs and supporting phylogenetic conclusions in cultivated potato. We show, with microsatellite (simple sequence repeat, SSR) and plastid DNA marker data, that Neo-Tuberosum germplasm is closely related to Chilotanum Group landraces from lowland south-central Chile rather than to Andigenum Group germplasm. We interpret this quite unexpected result
\end{abstract}

Communicated by C. Gebhardt.

Electronic supplementary material The online version of this article (doi:10.1007/s00122-008-0953-6) contains supplementary material, which is available to authorized users.

M. Ghislain $(\bowtie) \cdot$ J. Núñez $\cdot$ M. R. Herrera

Applied Biotechnology Laboratory,

International Potato Center (CIP), P.O. Box 1558, Lima 12, Peru

e-mail:m.ghislain@cgiar.org

D. M. Spooner

Vegetable Crops Research Unit, Agricultural Research Service, Department of Horticulture, U.S. Department of Agriculture, University of Wisconsin, 1575 Linden Drive,

Madison, WI 53706-1590, USA to be caused by strong rapid selection against the original Andigenum clones after unintended hybridization with Chilotanum Group germplasm. In addition, we show that Neo-Tuberosum and Andigenum Group germplasm did not serve to broaden the overall genetic diversity of advanced potato varieties, but rather that Neo-Tuberosum lines and lines not using this germplasm are statistically identical with regard to genetic diversity as assessed by SSRs. These results question the long-standing Neo-Tuberosum derived theory and have implications in breeding programs and phylogenetic reconstructions of potato.

\section{Introduction}

The origin of the "European" potato (cultivated potato first appearing in Europe and then spreading worldwide) has been controversial for nearly a century since the Russian potato scientists Juzepczuk and Bukasov (1929) supposed it as derived from landraces of Chilean origin, growing at Chiloé Island and the Chonos Archipelago to the south. The morphological resemblance and the capacity to tuberize under long-day conditions were the two main arguments for a Chilean origin. The tetraploid cultivated potato Solanum tuberosum has been long recognized as divided into two entities either referred to as species (Bukasov 1971; Lechnovich 1971), sub-species (Hawkes 1990; Ochoa 1990) or Cultivar Groups (Dodds 1962; Huamán and Spooner 2002; Spooner et al. 2007). S. tuberosum Andigenum Group is distributed from western Venezuela south to northern Argentina, and S. tuberosum Chilotanum Group, formerly referred to as the Tuberosum Group, from lowland Chile in Chiloé Island and the islands of the Chonos Archipelago to the south (Huamán and Spooner 2002). For simplicity of discussion in this paper we refer to $S$. tuberosum 
Andigenum Group as "Andigenum" and S. tuberosum Chilotanum Group as "Chilotanum" (referred to as Tuberosum in most potato breeding literature). Andigenum germplasm tuberizes poorly in the long days of the temperate latitudes, and the ability to rapidly select Andigenum for long-day length tuberization has been a big part of the long-standing controversy on the origin of the European potato (Ames and Spooner 2008).

In contrast, a number of potato scientists proposed or supported an Andigenum origin of the European potato (Salaman 1937; Salaman and Hawkes 1949; Glendinning 1975b; Hosaka and Hanneman 1988). This long-standing view was based partly on the production of Neo-Tuberosum potatoes, and on a range of other historical arguments (Ames and Spooner 2008). In 1959, Simmonds initiated a long-term experiment at the John Innes Institute to select modern potato characteristics from germplasm of exclusive Andigenum origin (Simmonds 1966). He started with 3,300 seedlings of about 300 Andigenum accessions, from geographically wide sources in Colombia, Peru, and Bolivia. He bred these through two sexual generations in a field with open pollination, and mass selected them for 5 years, primarily for day-length adaptation as expressed by greater tuber production in the long days of the UK. At the end of the experiment he produced a population he designated to be "half way" from the original Andigenum to Chilotanum relative to a range of characters that he referred to as the "day length syndrome." These included earlier tuberization, fewer and shorter stems, less flowering, shorter stolons, greater yield, larger leaves, less pigmented, smoother tubers, fewer but larger tubers, fewer seeds per fruit, and late blight and virus X and Y resistance. Simmonds (1969) named this new advanced potato germplasm "Neo-Tuberosum". The material was later transferred to the Scottish Crop Research Institute where it was further intercrossed (Glendinning 1975a) and characterized with respect to Andigenum and Tuberosum traits (Glendinning 1975b). Similar to previous observations by Simmonds (1966), Neo-Tuberosum appeared to have intermediate characteristics between Andigenum and Chilotanum. It was shown to be a highly diverse set of germplasm with a wide range of desirable traits that was thought to be lacking in existing advanced cultivars such as viruses $\mathrm{X}$ and $\mathrm{Y}$ and wart resistance provided by the Andigenum germplasm (Glendinning 1975c).

The ability to rapidly adapt Andigenum germplasm to a Chilotanum-like form and day length response was used as one part of a multi-component argument supporting Andigenum germplasm, rather than Chilotanum germplasm, as the progenitor of the European potato (Hawkes 1956; Simmonds 1978; Hosaka and Hanneman 1988). The Chilean origin hypothesis (Juzepczuk and Bukasov 1929) was relegated to history and the Andigenum origin was universally accepted for the past 40 years.
The late blight epidemic beginning in the UK in 1845 was seen as a turning point in shifting from the initial Andigenum introductions to Chilotanum introductions, which, through interbreeding, gave rise to modern cultivars being hybrids of the two Cultivar groups. There were many problems with this theory, including general lack of late blight resistance in Chilean germplasm (Bukasov 1933; Glendinning 1975d; Jansky 2000) and cytoplasmic male sterility of the Chilotanum serving mainly as female (Grun 1979). The incompatibility is especially significant because well over $99 \%$ of modern cultivars contain Chilotanum cytoplasm (Corriveau and Coleman 1988). However, this incompatibility is not absolute and many modern varieties produce pollen and can serve as a male breeding source.

Neo-Tuberosum development was quickly envisioned as a valuable pre-breeding program useful to gain access to the wide Andigenum diversity of traits not easily found in Chilotanum landraces or modern cultivars, by eliminating the unfavorable characteristics which had impaired its use in breeding in the past (Simmonds 1966, 1993). It inspired a new generation of potato breeders to practice the concept of germplasm enhancement by base broadening breeding using Neo-Tuberosum and the Andigenum landraces germplasm (Glendinning 1975c). In 1965, the potato breeding program at Cornell University took over the material from John Innes Institute and bred it with Andigenum landraces from South America (Plaisted 1972; Rasco et al. 1980; Muñoz and Plaisted 1981). After several years of breeding and selection, this program provided Neo-Tuberosum material to many breeding programs worldwide including the International Potato Center (CIP, in Lima Peru). The latter institution developed advanced breeding lines with resistance to early blight, late blight, viruses $\mathrm{X}$ and $\mathrm{Y}$, and important progenitors of true potato seeds (FernandezNorthcote et al. 1986). However, not all breeding programs, in particular private ones, adopted the concept of base broadening using Neo-Tuberosum and Andigenum germplasm shading already doubts about the real impact on varietal improvement.

The original purpose of our study was to quantify the degree of genetic base broadening of modern varieties and breeders' lines with respect to Andigenum and Chilotanum landraces. We assessed this base broadening with a representative sample from the CIP potato collection that is currently grown world wide including Neo-Tuberosum original clones, and their derivatives. We assessed overall diversity with simple sequence repeats (SSRs or microsatellites) that represent a refinement (paper in review; Herrera et al. 2006) of a set of SSR markers chosen to represent all 12 potato linkage groups, highly polymorphic and with no selected function (Ghislain et al. 2004). To assess maternal contributions of Andean and Chilean germplasm we also screened these materials with a 241-bp 
plastid deletion marker in the $t r n \mathrm{~V}-\mathrm{UAC} / n d h \mathrm{C}$ intergenic region of the plastid DNA molecule, which is absent in 94\% (or 95\%) of the Andean tetraploid landraces and present in $86 \%$ (or $81 \%$ ) of the tetraploid Chilean landraces, depending on the studies of Hosaka (2004) or Spooner et al. (2007).

\section{Materials and methods}

Plant material

A total of 688 tetraploid potato accessions were examined. These include: (1) six "pure" clones of Neo-Tuberosum that derive from the Neo-Tuberosum materials generated at Cornell University from the original populations developed by Simmonds, (2) 33 varieties or breeders' lines developed with Neo-Tuberosum in their pedigree; of these, 25 had Neo-Tuberosum as a female parent and the other 8 had Neo-Tuberosum as a male parent, (3) 154 varieties or breeders' lines without Neo-Tuberosum in their pedigree, chosen from the CIP genebank selected to cover a wide range of modern germplasm of cultivated potato from around the world; included here are three breeding clones [B1C4 clone Andigenum $\times$ Andigenum and ICA NEVADA Phureja $\times$ Andigenum, San Antonio Abad (Tuberosum $\times$ Andigenum) $\times$ Andigenum] serving as controls of Andigenum-based breeding and 15 unclassified putative tetraploid landraces that likely represent Andigenum $\times$ Chilotanum hybrids, (4) 305 of Andigenum landraces, (5) 190 Chilotanum landraces. The latter two groups of germplasm are those used in a previous study (Spooner et al. 2007) compared with 55 Andigenum and 164 Chilotanum accessions. The list of the 1-3 germplasm materials is deposited as a supplementary data file including the assignation of their taxonomic unit based on pedigree information available at CIP and in the literature.

DNA extraction, SSR primers, PCR conditions and electrophoresis

Genomic DNA was obtained by using standard protocols at CIP (Herrera and Ghislain 2000). DNA concentration was calculated by using PicoGreen dsDNA quantification reagent and a TBS-380 Fluorometer (Turner BioSystems). DNA dilutions were performed to achieve a final concentration of $3 \mathrm{ng} / \mu \mathrm{l}$ using 96-well plates. We used 24 SSR markers from a new Potato Genetic Identity kit (Table 1; paper under review; Herrera et al. 2006) that updates one by Ghislain et al. (2004). PCR reactions were performed and carried out as described in Spooner et al. (2007). PCR products were separated by electrophoresis on a LI-COR 4300 DNA Analyzer System.
SSR allele scoring

Simple sequence repeat alleles were detected and scored using the SAGA Generation 2 software (LI-COR, USA). The SSR alleles were identified by their size in base pairs of the upper band of the allele and scored as present (1), absent (0), or missing (9). Missing data were less than $5 \%$ $(3.8 \%)$ which is acceptable for cluster analysis.

\section{Cluster analysis}

Genetic analysis was performed by using the program DARwin 5.0 (Perrier and Jacquemoud-Collet 2006). We used Jaccard's similarity coefficient and $50 \%$ of minimal proportion of valid data required for each unit pair for cluster analysis. The dendrogram was built by using the Neighbor-joining method.

\section{Plastid DNA marker analysis}

The $241 \mathrm{bp}$ plastid deletion marker was analyzed for all 688 landrace accessions by using the PCR primers and protocols from Hosaka (2002). PCR products were separated by electrophoresis on a $1 \%$ agarose gel, and Lambda phage digested by PstI was used as a molecular weight marker. The $241 \mathrm{bp}$ deletion polymorphism was determined for size in base pairs and scored as " $\mathrm{T}$ " (with the deletion) or " $\mathrm{X}$ " (lacking it) based on clearly separating bands.

Data repository

Simple sequence repeat marker data were deposited in two SSR databases available on line from the bioinformatics portal of the Generation Challenge Program web site (http:// www.generationcp.org) and of CIP (http://research.cip. cgiar.org/confluence/display/IPD/SSR+Marker). These list full descriptions of each SSR marker, amplification and detection conditions, and the genotyping data of all potato landraces available to date from this and previous studies.

\section{Results}

The plastid DNA marker typical of Chilotanum germplasm was present in one of the six pure Neo-Tuberosum clones. Seven of the 12 varieties and breeders' lines with NeoTuberosum as direct female parent present the plastid DNA marker typical of Chilotanum germplasm which is rare among Andigenum germplasm. SSR markers grouped the six pure Neo-Tuberosum clones and all Neo-Tuberosum derived varieties and breeding lines entirely with the Chilotanum cluster instead of the Andigenum cluster (Fig. 1). This is in contrast with the three breeding controls 
Table 1 SSR markers used to genotype the 193 varieties and breeders' lines (VBL), 305 accessions of Andigenum (ADG) and 190 accessions of Chilotanum (CHL), as well as number of alleles identified and polymorphic index content (PIC) per SSR locus

\begin{tabular}{|c|c|c|c|c|c|c|c|c|c|}
\hline Name & Map & Total alleles & Total PIC & Alleles ADG & PIC ADG & Alleles CHL & PIC TBR & Alleles VBL & PIC VBL \\
\hline STM5127 & I & 15 & 0.853 & 15 & 0.858 & 13 & 0.800 & 12 & 0.797 \\
\hline STG0016 & I & 14 & 0.764 & 12 & 0.801 & 9 & 0.763 & 12 & 0.763 \\
\hline STM1064 & II & 9 & 0.576 & 7 & 0.584 & 8 & 0.648 & 8 & 0.659 \\
\hline STM5114 & II & 11 & 0.712 & 9 & 0.676 & 6 & 0.744 & 8 & 0.726 \\
\hline STM1053 & III & 10 & 0.675 & 9 & 0.687 & 6 & 0.597 & 5 & 0.618 \\
\hline STG0010 & III & 14 & 0.710 & 9 & 0.668 & 9 & 0.746 & 11 & 0.721 \\
\hline STI0001 & IV & 8 & 0.736 & 7 & 0.713 & 8 & 0.778 & 7 & 0.803 \\
\hline STI0012 & IV & 12 & 0.816 & 11 & 0.813 & 9 & 0.844 & 10 & 0.822 \\
\hline STPoAc58 & $\mathrm{V}$ & 12 & 0.736 & 11 & 0.810 & 9 & 0.528 & 9 & 0.673 \\
\hline STI0032 & $\mathrm{V}$ & 8 & 0.772 & 8 & 0.775 & 8 & 0.789 & 8 & 0.811 \\
\hline STI0004 & VI & 12 & 0.689 & 10 & 0.729 & 8 & 0.746 & 8 & 0.772 \\
\hline STM0019 & VI & 28 & 0.834 & 28 & 0.866 & 8 & 0.755 & 17 & 0.815 \\
\hline STI0033 & VII & 9 & 0.618 & 8 & 0.638 & 9 & 0.756 & 7 & 0.761 \\
\hline STM0031 & VII & 11 & 0.742 & 9 & 0.764 & 8 & 0.760 & 9 & 0.750 \\
\hline STM1104 & VIII & 14 & 0.854 & 12 & 0.874 & 12 & 0.792 & 10 & 0.743 \\
\hline STI0003 & VIII & 15 & 0.759 & 14 & 0.777 & 8 & 0.764 & 9 & 0.762 \\
\hline STM1052 & IX & 18 & 0.810 & 16 & 0.846 & 8 & 0.749 & 10 & 0.744 \\
\hline STI0014 & IX & 10 & 0.702 & 9 & 0.693 & 5 & 0.671 & 6 & 0.681 \\
\hline STG0025 & $\mathrm{X}$ & 7 & 0.550 & 6 & 0.507 & 4 & 0.508 & 5 & 0.546 \\
\hline STM1106 & $\mathrm{X}$ & 18 & 0.825 & 16 & 0.834 & 10 & 0.788 & 11 & 0.713 \\
\hline STM0037 & XI & 18 & 0.798 & 16 & 0.815 & 12 & 0.805 & 12 & 0.818 \\
\hline STG0001 & XI & 18 & 0.758 & 15 & 0.770 & 13 & 0.785 & 14 & 0.789 \\
\hline STM5121 & XII & 9 & 0.743 & 7 & 0.718 & 8 & 0.623 & 9 & 0.719 \\
\hline STI0030 & XII & 19 & 0.840 & 17 & 0.843 & 11 & 0.828 & 12 & 0.819 \\
\hline Total or Average & - & 319 & 0.745 & 281 & 0.752 & 209 & 0.732 & 229 & 0.743 \\
\hline
\end{tabular}

resulting of Andigenum-based breeding and selection which grouped with the Andigenum cluster as expected.

For the entire data set of 688 accessions examined, a total of 319 alleles were identified from 24 SSR markers with an average of 13.3 alleles per marker. Two hundred and twenty-nine alleles $(71.8 \%)$ were identified within the variety and breeders' lines with an average of 9.5 alleles per marker and the polymorphic index content (PIC) of all 688 accessions ranged from 0.550 to 0.854 with an average of 0.745 (Table 1 ).

Cluster analyses revealed a well-defined cluster of the varieties and breeders' lines grouping together with the Chilotanum landraces, completely separate from the Andigenum landraces (Fig. 1).

Fourteen $(6.1 \%)$ of the 229 SSR alleles were found only in the varieties and breeders' lines. One had a frequency of $2.3 \%$ while the other was below $1 \%$. The average PIC (0.743) is statistically indistinguishable from those of groups of native potatoes ( $\mathrm{PIC}=0.752$ for Andigenum, and $\mathrm{PIC}=0.732$ for Chilotanum) which illustrates the high genotypic diversity of the breeding material from CIP.
The plastid DNA deletion marker characteristic of Chilotanum landraces was found in $46 \%$ of the varieties and breeders' lines in comparison to $73.2 \%$ of the Chilotanum landraces and $4.6 \%$ in the Andigenum landraces.

\section{Discussion}

The finding that all six "pure" Neo-Tuberosum and the 33 Neo-Tuberosum derivatives group, without exception, with the Chilotanum rather than with the Andigenum cluster leads us to conclude that the Neo-Tuberosum materials are clearly not the product of strict inter-Andigenum breeding. The three Andigenum-based breeding controls falling in the Andigenum cluster and the fact that the SSR alleles are widely dispersed neutral markers not chosen for linkage to Chilotanum traits (Ghislain et al. 2004) validate this conclusion based on the analysis of the SSRs and the plastid marker.

This completely unexpected result has possibly two explanations which may or may not have occurred together. One explanation is supported by tracing the events which 
Fig. 1 Dissimilarity tree using Neighbor-joining cluster analysis of (1) Six "pure" accessions of Neo-Tuberosum (Neo-tbr) that represent some of the original populations developed by Plaisted from Simmonds materials (green), (2) 33 varieties or breeders' lines developed with Neo-Tuberosum in their pedigree (purple), (3) 154 varieties or breeders' lines without NeoTuberosum in their pedigree chosen from the CIP genebank selected to cover a wide range of modern germplasm of cultivated potato around the world (orange), (4) 305 of Andigenum landraces (blue), (5) 190 Chilotanum landraces (gray). Also are indicated the three breeding clones serving as controls of Andigenum-based breeding

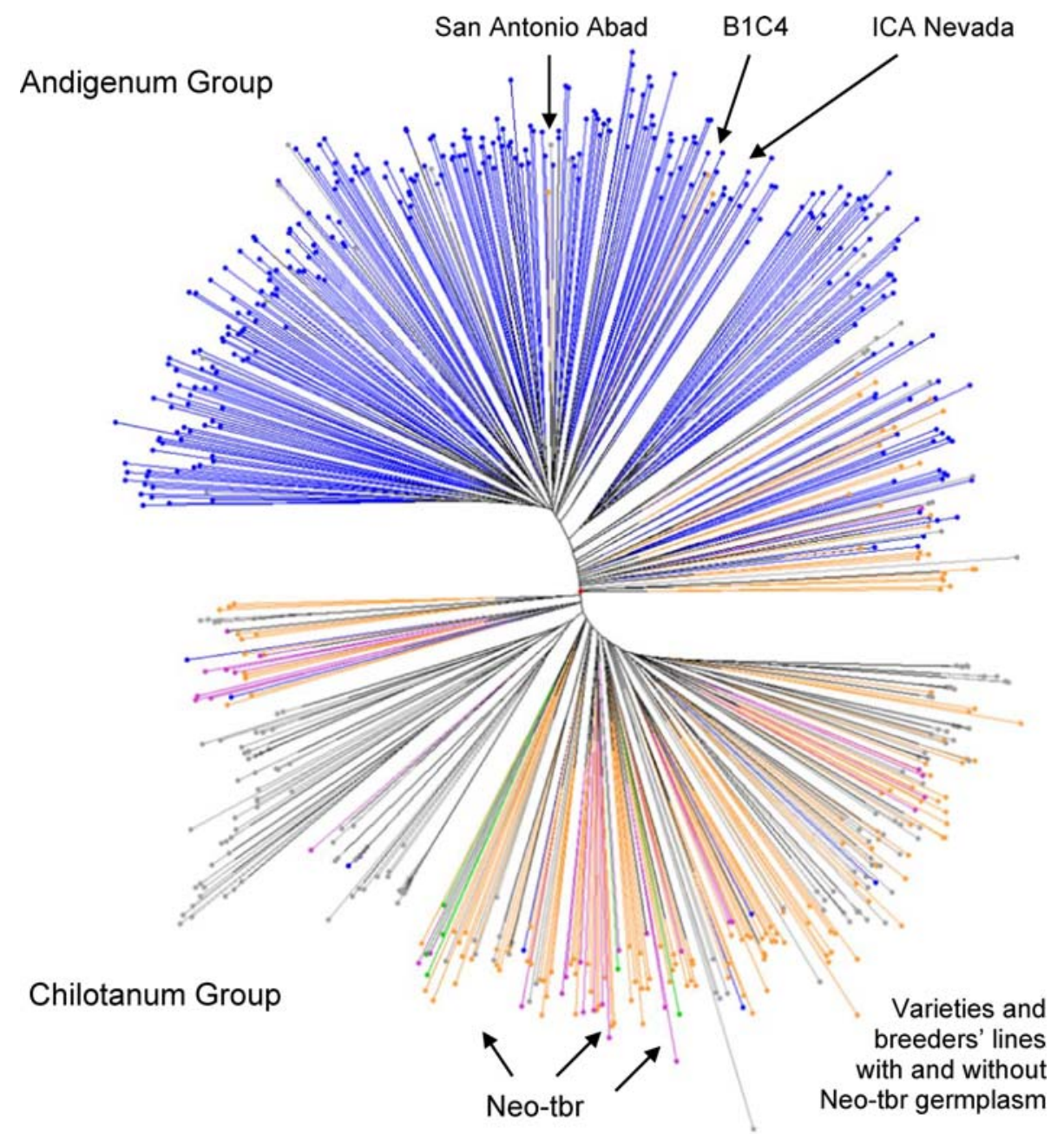

led to the original Neo-Tuberosum stocks. The initiation of the first Neo-Tuberosum populations was done "by some hundreds yards" away from modern cultivars (Simmonds 1966) which led Simmonds (1966) to state that out-pollination "was at worst infrequent and probably non-existent". Potatoes require vibratile buzzing to release pollen, and bumblebees are their main pollinators (Johns and Keen 1986; Scurrah et al. 2008). Bumblebees typically forage over 70-631 m (Osborne et al. 1999), but pollen from one flower is usually deposited only across a limited number that are subsequently visited and gene flow is generally restricted to very near neighbors (McPartlan and Dale 1994; Scurrah et al. 2008). Only about $20 \%$ of seeds were cross-pollinated in the original Neo-Tuberosum experiment (Glendinning 1976). These and factors such as residence time in one crop favors highly localized cross-pollination of plants near the pollen source (Cresswell et al. 2002). Therefore, it seems unlikely that after only two recombination cycles in the field, the population would have become "half way" towards modern varieties by only pollen contamination from nearby modern variety plots. In addition to possible gene flow from Chilotanum adjacent fields, the
Neo-Tuberosum generation plots could have gained genes from modern varieties within the field from volunteers of modern potato varieties which were found later to be present and recognized to be a possible source of contamination in the early cycles of the re-creation experiment (Glendinning 1976). Hence, this first possible explanation, gene flow from adjacent fields, and from volunteers within the NeoTuberosum fields cannot be excluded from the first years of the Neo-Tuberosum experiment. As this original and derived material was distributed to other partners later on who confirmed the Neo-Tuberosum theory, an early contamination with germplasm from modern varieties might have completely skewed their conclusions.

A second explanation may be the misidentification of the original genetic stocks. The plant material used in the original John Innes Institute studies in UK was from the Andigenum stocks from the Commomwealth Potato Collection. Described by Glendinning (1975a), this material is of $43 \%$ Bolivian, $35 \%$ southern Peruvian, and about $10 \%$ northern Peruvian and Colombian origin. This collection may have had misidentified accessions of Chilotanum as Andigenum. In the early days of potato collection, all 
tetraploid landraces from the highland Andes were automatically included into Andigenum. However, a closer look at some of Andean landrace accessions reveals mixed characteristics of Andigenum and Chilotanum (unpublished data at CIP) revealing the difficulties in identifying some accessions. These are referred sometimes as Andigenum $\times$ Chilotanum or vise versa and assumed to be natural hybrids although no evidences are provided except for intermediate morphological characteristics (unpublished data at CIP). These accessions could also be re-introductions from Chiloé or hybrids with modern potato varieties. The latter seems, however, the least probable due to frequent pollen sterility of modern potato varieties and limited, if any, introduction of modern varieties in southern Peru and Bolivia.

The genetic analysis of the variety and breeders' lines reveal that these group with Chilotanum landraces rather than with Andigenum landraces, and that there is no statistically significant difference in genotypic diversity as assessed by SSRs (Table 1). Both modern varieties and breeders' lines present a high level of diversity and interestingly few unique SSR alleles (14 out of 229) possibly reflecting the introgression of DNA from potato wild species. Indeed, SSR markers were shown to amplify also in several Solanum species (Merino et al. 2006). The high frequency of the plastid marker in variety and breeders' lines reflects also the importance of the Chilotanum germplasm into their pedigrees. Hence, breeders who have incorporated Andigenum and wild species germplasm following the base-broadening approach have apparently applied a strong negative selection against the Andigenum type when identifying future successful clones. A plausible explanation could be that the desirable features of a cultivated potato, such as adaptation under long-day conditions, superficial eyes, oblong tubers, and possibly others, are present mainly in the Chilotanum germplasm and rarely in the Andigenum germplasm. Such observations reveal that the base-broadening approach using Andigenum germplasm for breeding modern potatoes does not result in major incorporation of genetic factors from the Andigenum germplasm.

Our data are parallel to those of Douches et al. (1991) who documented, with isozyme data, mistaken pedigrees of many nineteenth century potato cultivars. Like us, they ascribed some of these errors to unappreciated hybridization in open-pollinated fields. Apparently, gene flow is common enough that establishing pedigrees by breeding programs based on open pollination is not always reliable and one may question the pedigrees of potato varieties not produced by controlled pollination.

Acknowledgments The authors are grateful to Enrique Grande for verifying and updating pedigree information and Dr. Shelley Jansky for providing useful comments on a previous version of this manuscript. This research was supported by the Grant SP1C2-2004-5 from the Generation Challenge Program, the International Potato Center, and by U.S. National Science Foundation Division of Environmental Biology (NSF DEB) 0316614 entitled: a world-wide treatment of Solanum (http://www.nhm.ac.uk/research-curation/projects/solanaceaesource//).

Open Access This article is distributed under the terms of the Creative Commons Attribution Noncommercial License which permits any noncommercial use, distribution, and reproduction in any medium, provided the original author(s) and source are credited.

\section{References}

Ames M, Spooner DM (2008) DNA from herbarium specimens settles a controversy about origins of the European potato. Am J Bot 95:252-257

Bukasov SM (1933) The potatoes of South America and their breeding possibilities. Bull Appl Bot Genet Plant Breed Suppl 58:154-192

Bukasov SM (1971) Cultivated potato species. In: Bukasov SM (ed) Flora of cultivated plants, vol IX. Kolos, Leningrad, pp 5-40

Corriveau JL, Coleman AW (1988) Rapid screening method to detect potential biparental inheritance of plastid DNA and results for over 200 angiosperm species. Am J Bot 75:1443-1453

Cresswell JE, Osborne JL, Bell SA (2002) A model of pollinator-mediated gene flow between plant populations with numerical solutions for bumblebees pollinating oilseed rape. Oikos 98:375-384

Dodds KS (1962) Classification of cultivated potatoes. In: Correll DS (ed) The potato and its wild relatives. Contr Texas Res Found. Bot Stud 4:517-539

Douches DA, Ludlam K, Freyre R (1991) Isozyme and plastid DNA assessment of pedigrees of nineteenth century potato cultivars. Theor Appl Genet 82:195-200

Fernandez-Northcote EN, Mendoza HA, Galvez R (1986) Breeding for potato virus Y (PVY) immunity combined with earliness and tolerance to heat. Am Potato J 63:422-423

Ghislain M, Spooner DM, Rodríguez F, Villamón F, Núñez J, Vásquez C, Waugh R, Bonierbale M (2004) Selection of highly informative and user-friendly microsatellites (SSRs) for genotyping of cultivated potato. Theor Appl Genet 108:881-890

Glendinning DR (1975a) Neo-Tuberosum: new potato breeding material. 1. The origin, composition, and development of the Tuberosum and Neo-Tuberosum gene pools. Potato Res 18:256-261

Glendinning DR (1975b) Neo-Tuberosum: new potato breeding material. 2. A comparison of Neo-Tuberosum with unselected Andigena and with Tuberosum. Potato Res 18:343-350

Glendinning DR (1975c) Neo-Tuberosum: new potato breeding material. 3. Characteristics and variability of Neo-Tuberosum, and its potential value in breeding. Potato Res 18:351-362

Glendinning DR (1975d) Chilean potatoes: an appraisal. Potato Res 18:306-307

Glendinning DR (1976) Neo-Tuberosum: new potato breeding material. 4. The breeding system of Neo-Tuberosum, and the structure and composition of the Neo-Tuberosum gene-pool. Potato Res 19:27-36

Grun P (1979) Evolution of cultivated potato: a cytoplasmic analysis. In: Hawkes JG, Lester RN, Skelding AD (eds) The biology and taxonomy of the Solanaceae. Academic Press, London, pp 655-665

Hawkes JG (1956) Taxonomic studies on the tuber-bearing Solanums. 1. Solanum tuberosum and the tetraploid species complex. Proc Linn Soc Lond 166:97-144

Hawkes JG (1990) The potato evolution, biodiversity and genetic resources. Belhaven Press, London, p 259 
Herrera MR, Núñez J, Guzman F, Ghislain M, Spooner DM (2006) A new potato genetic identity kit of 24 SSR markers for high throughput fingerprinting of large collections. In: VI international solanaceae conference, Madison

Herrera MR, Ghislain M (2000) Molecular biology laboratory protocols: plant genotyping, 3rd edn. Crop Improvement and Genetic Resources Department, Training Manual, International Potato Center (CIP), Lima

Hosaka K (2002) Distribution of the 241 bp deletion of chloroplast DNA in wild potato species. Am J Potato Res 79:119-123

Hosaka K (2004) Evolutionary pathway of T-type chloroplast DNA in potato. Am J Potato Res 81:153-158

Hosaka K, Hanneman RE Jr (1988) The origin of the cultivated potato based on chloroplast DNA. Theor Appl Genet 76:172-176

Huamán Z, Spooner DM (2002) Reclassification of landrace populations of cultivated potatoes (Solanum sect. Petota). Am J Bot 89:947-965

Jansky SH (2000) Breeding for disease resistance in potato. Plant Breed Rev 19:69-155

Johns T, Keen S (1986) Ongoing evolution of the potato on the altiplano of western Bolivia. Econ Bot 4:409-424

Juzepczuk SW, Bukasov SM (1929) A contribution to the question of the origin of the potato. Tr Vses Szeda Genet Selek 3:593-611 (in Russian, English summary)

Lechnovich VS (1971) Cultivated potato species. In Bukasov SM (ed) Flora of cultivated plants, chap 2, vol IX. Kolos, Leningrad, pp 41-304

McPartlan HC, Dale PJ (1994) An assessment of gene-transfer by pollen from field-grown transgenic potatoes to non-transgenic potatoes and related species. Transgenic Res 3:216-225

Merino CG, Herrera MR, Ghislain M, Rodriguez F, Spooner DM (2006) Divergence of microsatellite loci between wild and cultivated potatoes. In: Proceedings of the XIV plant, animal and microbe genomes conference, San Diego, 14-18 January, P143

Muñoz FJ, Plaisted RL (1981) Yield and combining abilities in Andigena potatoes after six cycles of recurrent phenotypic selection for adaptation to long day conditions. Am Potato J 58:469-479
Ochoa CM (1990) The potatoes of South America: Bolivia. Cambridge University Press, Cambridge

Osborne JL, Clark SJ, Morris RJ, Williams IH, Riley JR, Smith AD, Reynolds DR, Edwards AS (1999) A landscape-scale study of bumble bee foraging range and constancy, using harmonic radar. J Appl Ecol 36:519-533

Perrier X, Jacquemoud-Collet JP (2006) DARwin software. http:// darwin.cirad.fr/darwin

Plaisted RL (1972) Prospect for the potato in the developing world. International Potato Center, Lima, pp 90-99

Rasco ET, Plaisted RL, Ewing EE (1980) Photoperiod response and earliness of $S$. tuberosum ssp. Andigena after six cycles of recurrent selection for adaptation to long days. Am Potato J $57: 435-448$

Salaman RN (1937) The potato in its early home and its introduction into Europe. J R Hortic Soc 62:61-67, 112-113, 156-162, 253266

Salaman RN, Hawkes JG (1949) The character of the early European potato. Proc Linn Soc Lond 161:71-84

Scurrah M, Celis-Gamboa C, Chumbiauca S, Salas A, Visser RGF (2008) Hybridization between wild and cultivated potato species in the Peruvian Andes and biosafety implications for deployment of GM potatoes. Euphytica 164:881-892

Simmonds NW (1966) Studies of the tetraploid potatoes. III. Progress in the experimental re-creation of the Tuberosum group. J Linn Soc (Bot) 59:279-288

Simmonds NW (1969) Prospects of potato improvement. Scott Plant Breed Stn Ann Rep 48:18-38

Simmonds NW (1978) Neotuberosum and the genetic base in potato breeding. ARC Res Rev 2:9-11

Simmonds NW (1993) Introgression and incorporation. Strategies for the use of crop genetic resources. Biol Rev 68:539-562

Spooner DM, Núñez J, Trujillo G, Herrera MR, Guzmán F, Ghislain M (2007) Extensive simple sequence repeat genotyping of potato landraces supports a major reevaluation of their gene pool structure and classification. Proc Natl Acad Sci USA 104:1939819403 